\title{
Article
}

\section{Representation of poverty in Polish, Lithuanian and Latvian documentary films of the post-communist period}

Mazierska, Ewa Hanna and Šukaitytè, Renata

Available at http://clok.uclan.ac.uk/22671/

Mazierska, Ewa Hanna ORCID: 0000-0002-4385-8264 and Šukaitytè, Renata (2020) Representation of poverty in Polish, Lithuanian and Latvian documentary films of the post-communist period. Studies in Eastern European Cinema, 11 (1). pp. 67-81. ISSN 2040-350X

It is advisable to refer to the publisher's version if you intend to cite from the work. http://dx.doi.org/10.1080/2040350x.2018.1465672

For more information about UCLan's research in this area go to http://www.uclan.ac.uk/researchgroups/ and search for < name of research Group>.

For information about Research generally at UCLan please go to http://www.uclan.ac.uk/research/

All outputs in CLoK are protected by Intellectual Property Rights law, including Copyright law. Copyright, IPR and Moral Rights for the works on this site are retained by the individual authors and/or other copyright owners. Terms and conditions for use of this material are defined in the policies page.

\section{CLoK}

Central Lancashire online Knowledge www.clok.uclan.ac.uk

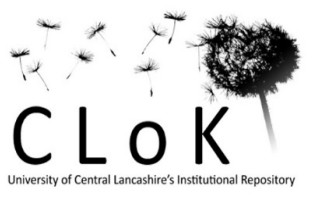




\section{Representation of Poverty in Polish, Lithuanian and Latvian Documentary Films of the Postcommunist Period}

Ewa Mazierska (The University of Central Lancashire, EHMazierska@uclan.ac.uk)

Renata Šukaitytė (Vilnius University, renata.sukaityte@kf.vu.lt)

Keywords: poverty, poverty culture, social pathology, Eastern Europe, Latvian documentary, Lithuanian documentary, Polish documentary,

This article examines representation of poor families in three documentary films from the Baltic region, produced after the fall of state socialism: Ewa Borzęcka's 13 or Trzynastka (Thirteen, 1996, Poland), Marat Sargsyan's Tèvas (Father, 2012, Lithuania), and Andris Gauja's Gimenes lietas (Family Instinct, 2010, Latvia). Each film does so by focusing on a family which does not fit into the dominant notion of a 'decent' or 'conventional' family and instead fits the idea of a 'pathological family'. Accordingly, we are interested in the way poverty in these films is linked to social pathology and a wider neoliberal project. Our argument is that by foregrounding such a connection the filmmakers absolve the state from responsibility for ensuring a decent standard of living for all citizens. Before we move to the films, we shall explain the meaning of the term 'poverty' and its use during the period of state socialism and after its collapse.

\section{Culture of poverty in Latvia, Lithuania and Poland}

The meaning of 'poverty' is far from straightforward. What constitutes poor person in one culture, might not fit another one. For this reason, authors differentiate between absolute and relative poverty. Absolute poverty is defined in terms of survival; more commonly it refers to subsistence, linked to a basic standard of physical capacity necessary for production of (paid work) and reproduction (bearing and nurturing children). Nutrition is central to such definition' (Lister 2004, 21). According to Karl Marx, poverty understood in such terms is a fate of the proletariat under the conditions of capitalism. Capitalists do not care about the wellbeing of their workforce and their families. The only thing that matters is their reproduction.

A relative poverty happens when individuals, families, and groups in the population 'lack the resources to obtain the types of diet, participate in the activities, and have the living conditions 
and amenities, which are customary, or are at least widely encouraged or approved, in the societies to which they belong. Their resources are so seriously below those commanded by the average individual or family that they are, in effect, excluded from ordinary living patterns and activities' (Townsend 1979, 31).

An important term from our perspective is also culture of poverty, coined by a sociologist and anthropologist Oscar Lewis. Lewis suggests to look into poverty as a certain 'design of living which is passed down from generation to generation' (Lewis 1963, xxiv). He points out into a certain pattern of beliefs, feelings and behaviour, which hangs together and claims that, '(...) it is a way of life, remarkably stable and persistent, passed down from generation to generation along family lines' (Lewis 1963, xxiv). He believes that the culture of poverty has some universal characteristics which transcend regional, rural-urban, and even national differences (Lewis 1963, xxv). He grounds this belief in his comparative study of lower-class settlements in London, Glasgow, Paris, Harlem and Mexico City (Lewis 1959).

During state socialist period, according to the leaders of the Soviet Union and its satellite countries, poverty and inequality in this region simply did not exist. This is not true; there were cases of both absolute poverty, especially in Russia during the Second World War and of relative poverty, in the countryside and the provinces, when basic household goods and fresh foods were considered a luxury.

Mervyn Matthews in his seminal study on poverty in the Soviet Union put together the official data and outcomes of surveys of living standards and social system in the Soviet Union to grasp the specificity of poverty in this country. Majority of the Soviet people fit into category of the 'working poor' because of monetary poverty, severe material deprivation and low access to cultural and sport activities, especially in the countryside and the provinces. It is worth indicating that at a time single parents (mainly women), children living in pathological families, handicaps and pensioners, were at greatest poverty risk. However, the economic inequality and social segregation under state socialist regime was smaller and hence the notion of poverty was different than that in the West. Most of Soviet citizens didn't consider themselves impoverished because of lack of information about the opportunities of better life in the capitalist world, even though the wellbeing of low. This observation Daiva Kšivickienè made by conducting research on poverty in Lithuania (Kšivickienė 2006, 82).
Commented [R2]: I think in all republics including Russia people lived in relative or absolute poverty

Commented [gk3]: It will be good to find more sources on poverty under state socialism to beef it up. 
After introduction of neoliberalism in postcommunist Eastern Europe, social segregation and poverty have been increasing, despite the growth of the GDP in this region. According to Eurostat, the highest inequality in the EU in 2005, apart from Portugal, was to be found in three postcommunist countries: Poland, Latvia, Lithuania, and there has been a steady upward trend in inequality in the EU since 2000 (when the EU ratio was 4.5. (Eurostat data, http://www.poverty.org.uk/summary/eapn.shtml)). According to the study, the most impoverished groups remained single parents (mainly women), pensioners, multi-child families, and low educated adults and their children. The same tendency indicated the World Bank study on Growth, Poverty and Inequality. Eastern Europe and Former Soviet Union (2015), and a new Eurostat survey on poverty and social exclusion in the EU (2015). These surveys revealed that, no significant progress was made in reduction or poverty and social exclusion, especially in Eastern Europe (with exception of the Czech Republic), where monetary poverty and severe material deprivation is especially high in rural areas remained due to high unemployment, lower income and lack of social skills of rural citizens (Eurostat data http://ec.europa.eu/eurostat/statisticsexplained/index.php/Europe_2020_indicators_-_poverty_and_social_exclusion).

The economic and social inequalities have been usually justified by an ascent of the new ideology which promoted individualism, and competition. Those less fortunate were presented as victims of their own deficiencies, such as laziness and the lack of the education or entrepreneurial spirit and often labelled 'homo sovieticus': the relics of the old, state socialist system (ref Marody). This way, inability to adjust to the capitalist system is simply considered as certain 'social pathology' or even 'individual pathology'. Such approach to an individual was strongly criticized by Erich Fromm in The Sane Society (1955), where he discussed the pathology of normalcy and unadjustment of culture of the western society, and claimed that society should adjust to the needs of an individual, but not the contrary (Fromm 2001, 6). In the chapter on "Socialism" he claimed that 'Socialism in all its various schools can be understood only as one of the most significant, idealistic, and moral movements of our age' (Fromm 2001, 240), however, the Stalinist version of socialism 'in spite of its state ownership of the means of production, is perhaps closer to the early and purely exploitative forms of Western Capitalism than to any conceivable idea of a socialist society' (Fromm 2001, 241). For Fromm Soviet socialist system was even worse than Western Capitalism as it limited and oppressed people's freedom even more. Soviet Socialism discredited 
the socialist movement as an 'obsessional striving for industrial advance, ruthless disregard for the individual and greed for personal power are its mainsprings.' (Fromm 2001, 241).

In the light of the fact that poverty and social segregation is a widespread phenomenon in Eastern Europe, and especially in Latvia, Lithuania and Poland, it is understandable that it became a frequent topic of documentary cinema produced in them, given that documentary cinema, more than fiction films, offers the viewers less manicured images of reality and focuses on characters whom fiction films are reluctant to represent, such as victims of adverse circumstances (Winston 2008, 46-54) or 'others' (Nichols 2001, 3-13), as opposed to heroes and winners.

Among them we can list Mgła/Fog (1993), directed by Irena Kamieńska, Ta wspaniała praca/This Wonderful Work (1993), directed by Piotr Morawski, Koniec epoki wegla kamiennego/The End of the Epoch of Coal (1993), directed by Tomasz Dobrowolski, Šaltos ausys (Dear Ears, Linas Mikuta, 2016, Lithuania), Melleņu gari (Blueberry Spirits, Astra Zoldnere, 2016, Latvia), Sèkmès metai (Lucky Year, Rimantas Gruodis, 2014, Lithuania), Tèvas (Father, Marat Sargsyan, 2012, Lithuania), Liza, namo! (Lisa, Go Home!, Oksana Buraja, 2012, Lithuania), Stebuklu laukas (The Field of Magic, Mindaugas Survila, 2011, Lithuania), Šanxai Banzai (Shanghai Banzai Jūratè Samulionytė, 2010, Lithuania), Aš perèjau ugnì, tu buvai su manim (Through Fire I Went, You Were With Me, Audrius Stonys, 2010, Lithunia), Keturi žingsniai (Four Steps, Audrius Stonys, 2008, Lithuania), Tārps (The Worm, Andis Mizišs, 2005, Latvia), Gimenes lietas (Family Instinct, Andris Gauja, 2010, Latvia). It is worth mentioning that in Poland documentaries about poverty were made mostly in the 1990s and they typically linked poverty to de-industrialisation, following the fall of state socialism. Afterwards their number declined, while in Lithuania and Latvia they peaked in the 2000s. Although it is impossible to explain all reasons for these different waves of films about poverty, one likely factor was the crisis of 2008, which hit Baltic countries very strong, while leaving Poland practically intact.

Due to space constraints, we decided to focus on three films, Ewa Borzęcka's 13 or Trzynastka (Thirteen, 1996, Poland), Marat Sargsyan's Tèvas (Father, 2012, Lithuania), and Andris Gauja's Gimenes lietas (Family Instinct, 2010, Latvia) in which poverty befalls families rather than individuals. They portray three different family models (e.g. incestuous family; singleparent multi-child family; elderly (retired criminal) parents, multi-child family), which do not fit into the societal notion of a decent or conventional family. The images of poverty and the poor in 
these documentaries are recognizable for the viewers as 'the reality of poverty' is well coded and to put in Elizabeth Cowie's words is 'a socially constructed category' and thus 'is read through conventionally understood signs' (Cowie 1999, 30). However, Borzęcka, Gauja and Sargsyan apply different cinematic strategies for narrating stories of poverty in selected Polish, Latvian and Lithuanian families which will be discussed in detail in separate sections of this paper.

Certain traits of culture of poverty are noticeable in the life of the characters/participants of Thirteen, Father, and Family Instinct. Explicitly these movies portray the people who are at the very bottom of the socio-economic scale: they are unemployed or retired (with minimal retirement pension) or/and dependable on social aid. They all live in very poor housing conditions: self-built house/sheds located in the countryside or outskirts of the city. House inventory is worn out, mainly second handed: collected from dumps or donated by people. Their everyday diet is humble, as is their clothing and children's toys. They live in their claustrophobic world and have no knowledge about the world around them. According to Lewis' definitions, the culture of poverty would apply exactly to that kind of people (Lewis 1963, xxv). He claims that, 'The people in the culture of poverty have a strong feeling of marginality, of helplessness, of dependency, of not belonging. They are like aliens in their own country, convinced that the existing institutions do not serve their interests and needs. (...). They are marginal people who know only their own troubles, their own local conditions, their own neighborhood, their own way of life. (...).' (Lewis 2006, 21) Children who are born in poverty and raised by parents lacking social skills, having criminal backgrounds, and suffering from dependency are more likely to experience social exclusion and marginalization. The culture of poverty naturally becomes their culture, because as Jamie Gough, Adam Eisenschitz and Andrew McCulloch claim 'social segregation is fostered by social (spatial) practices such as, employment, residence, services, transport and friends networks' (Gough, Eisenschitz, McCulloch 2005, 131). Ewa Mazierska notices similar factors causing social segregation in Poland while analyzing new Moral Concern movies in book Polish Postcommunist cinema. From Pavement level where she writes that 'in postcommunist Poland social segregation begins early, in secondary, or perhaps even primary school, preventing working class children from achieving their potential' as poor people live in certain settlements, share the same infrastructure, etc. (Mazierska 2007, 148).

\section{Pornographic poverty in Thirteen by Ewa Borzęcka}


Ewa Borzęcka, the director of 13 or Trzynastka (Thirteen, 1996) was born in 1960 and started her career in the 1980s, and her greatest successes, Thirteen and Arizona (1997) came in the 1990s. Borzęcka follows people who are in many ways unusual, or represent an extreme case of a specific phenomenon. Often Borzęcka's films are set among communities at the end of their lives. This is the case with U Danusi (At Danusia, 2002), which presents the nearly desolate town of Julinek, in the past known for its circus and a school training circus artists, closed down in the 1990s, and $U$ nas na Pekinie (Amongs Us in Pekin, 2004), which tells a story of people in a run-down apartment bloc in the centre of Warsaw, which is about to be demolished.

The fact that Borzęcka chooses extreme cases and people living on the margin on the society makes it difficult to classify her work. Some viewers regard her as a socially concerned filmmaker who chooses such situations to illuminate more widespread phenomena, most importantly poverty, the neglect of rural communities and hardship of single parenting. Others see her intentions as less noble - stigmatizing people who live outside the mainstream and telling their stories in a way that they reassure the viewers about their normality and superiority of their position, while providing them pleasure of seeing something unusual and kinky, what in today's language is described as virtue-signalling. In our opinion Borzęcka leads towards the second strategy, that of 'pornographer' (Millington 2013) or 'dark tourist' (Lennon and Foley 2010), who revels in and plays up other people's poverty and misery for a stronger cinematic effect. At the same time, one cannot deny that her films, being documents, document something which exists in reality and this reality cannot be entirely controlled by the filmmaker with a specific agenda. In our analysis we will also draw attention to such moments.

Thirteen presents the life of a single mother with thirteen children. The film has no authorial commentary. Everything we hear are dialogues of its characters, mainly the mother and children, and some people with whom she interacts as well as off-screen comments of children and their mother. As with other films by Borzęcka, it is difficult to gain basic factual knowledge about characters, namely in which part of Poland do they live, what they do for living, how old they are and why they found themselves in a particular life situation. Such knowledge can be only inferred from the construction of the mise-en-scene and scraps of dialogues. This can be regarded as a sign of Borzęcka's refusal of didacticism, of telling the viewers what to think about her characters. In our view, however, it rather serves the author to convey a specific perspective on them, namely denying them normality. For example, we know that the woman is a single mother but till late we 
do not know who is or fathers of her children. Seeing her early on in a company of men drinking alcohol arises suspicions that she engages in a promiscuous sex. Only much later we learn that she is a widow, although the circumstances of her husband's death are never explained and hence we do not know whether the mother received any compensation following his passing away.

There is no doubt that the family in Borzęcka's film is poor. It fits the definition of relative poverty, as presented in the introductory part of this chapter and verges on absolute poverty. The best indicator of that is the food which they eat and their comments on food. Food is for them the most important thing in life and they divide people according to the amount and type of food they eat. One of the children says that rich people eat good food, such as meat and butter and they have plenty of it, while they eat mostly bread. At some point we see the mother buying over twenty loaves of bread, all on credit and bringing it back in large sacks. Other food we see children eating is that of home-made sauerkraut, made in the way it was done traditionally with children jumping with bare feet on cabbage so that the juice comes out. The rest of their diet is supplemented by what they catch in the wood: rabbits and fish. There is no cutlery in their home - all food is eaten with hands. This will be enough to see the family as reduced to primitive, animal-like existence, but Borzęcka plays up this aspect by focusing on animals and human interaction with animals. Even before we see the characters, when film titles are shown on screen, we hear animals - cats meowing wildly as if they were tortured or were engaged in a fight. This is indeed the case when the sound is accompanied by image. We see three cats kept by the children by their backs and brought close to other cats so that they attack each other with paws and meow to scare the other cat off. Obviously children (all boys) find it very funny and there is nobody in the room to stop this cruel entertainment. When the fight is over they inspect the cats to check their injuries. The scene of fighting cats is repeated several times throughout the film, suggesting that this is the main entertainment of the kids. We also see them fascinated by the images of cats hunting for mice, a cat fighting with a dog and animals showing signs of life after seemingly being killed. Apart from showing limited opportunities of entertainment, such images encourage allegorical reading - the family is like a pack of animals fighting for their extremely limited resources. However, by and large, the children seem to live in harmony with each other. The older children often help the younger. When the food is brought on the table, such as baked rabbit, the older take it first to pass it to the younger. Another context in which animals appear in Thirteen is when the mother talks with another family, presumably relatives or neighbours, about having her goat to copulate with 
the neighbor's goat. After that we see copulating goats. These episodes, particularly given that the mother herself mentions earlier that the people compared her to a sow due to the fact that she gave birth many times. There is no information where the family lives, although it looks like in a village somewhere in the mountains, but more likely at the outskirts of the village than at its centre. The house is made of wood and has minimal facilities. There is no bathroom and no gas or electrical heating; the house is heated by an old-fashioned stove using wood or coal.

Although it will be possible to present children as individuals, by showing how different they are from each other, this is not the case in the films. Their names remain unknown and any personal characteristics are curtailed, as encapsulated by the very title of the film. On most occasions we see children in small groups, engaging in physical rather than intellectual activities, such as eating, cutting bread or skinning a rabbit. If they are shown individually, like when they are washed by their mother, this is to present them as items on a conveyer belt, as one child is washed after another. There is no reference to them going to school, although the majority are in school age and school would be their main source of learning about a wider environment and an opportunity for social promotion. This adds to the sense that they are excluded from a wider world. There seems to be only two daughters of this single mother and they are excluded from play and have (literally) no voice. We only see them once for a short while. Such exclusion of women might be surprising in a film made by a woman, but might be explained by the fact that foregrounding girls might undermine the Darwinian vision of the family, offered by Borzęcka. For example, it is difficult to imagine that cat fight would yield as much pleasure to the girls than to the boys or that they will revel in the stories of burning rats' eyes.

Fighting, eating and copulating is what we see in the animal kingdom and it is how Borzęcka presents her characters. She also suggests a certain trajectory of the lives of the characters by including in the film a song Wolność (Freedom) by a Polish band Boys. It is sung by children rambling through the countryside, and serves as background music. Freedom is one of the greatest hits from of disco polo, a genre strongly identified with rural, provincial and backward Poland, especially popular among Polish prison community. The song tells a story of a mother who wanted her son to grow up to be somebody important, but who ended up in borstal.

And yet, despite Borzęcka's attempts to render the family as both animal-like and sentenced to social exclusion and possibly criminality, there are moments when the life of this family seems superior over the middle-class existence of the film's addressee. This is because the 
children are able to enjoy little things and capture the moment. For example, when there is snow they use any equipment available, such as a large bowl, to slide down the hill. Moreover, having so many siblings makes them immune to the arguably the greatest malaise of contemporary times: solitude. Such observations confirm the point made by Oscar Lewis that 'living immersed in the present [characteristic for poor people] may develop a capacity for spontaneity, for enjoyment of the sensual, the indulgence of impulse, which is too often blunted in our middle-class futureoriented man' (Lewis 2006, 21).

Given the consistency in Borzęcka's interest and her approach, it is natural to regard Thirteen as a work of a documentary auteur. However, it is also worth adding that the film was produced by Telewizja Polska - I Program - First Programme of Polish State Television, hence one can expect that it would reflect the dominant ideology, in this case the government view on poverty. And the film scores well on this account, divorcing the issue of poverty in postcommunist Poland from that of the collapse of the socialist welfare state and the neglect of rural communities. Instead, it suggests that poverty is a personal problem - in this case having too many children. Moreover, it does so in a subtle way, avoiding any commentary from the author and seemingly only showing how things are.

\section{Incest, poverty and battle for survival in Family Instinct by Andris Gauja}

In Andris Gauja Family Instinct we face a Latvian pathological family and their social environment. Zanda, the protagonist of the movie, lives together with her brother Valdis and raises two of his children on her own while Valdis is in prison for domestic violence. The family is settled in Latvian countryside where they share a little house with their biological mother, her boyfriend and his adult sons Andulis and Janis. Worth noting is that Zanda and Valdis were not brought up together as siblings because the right to raise her ten children was taken away from their mother. Most probably, the fact that they were brother and sister had no meaning for them, and did not prevent from creating a pathological family. In a conversation with Paul Zabrizzi, Gauja explained the incest with a psychological term 'genetic magnetism/attraction', which experience separated siblings when they meet for the first time being adults. He believes that for Zanda and Valdis, '(...) this fact that they were brother and sister was just a fact, that didn't have any emotional content. It is just a word with no meaning and that's very important' (Zabrizzi 2011). 
Family Instinct explicitly witnesses preconditioned social exclusion and poverty, which Lewis described as culture of poverty. All the characters live in poor housing and material conditions, share a strong feeling of marginality, helplessness, dependence and inferiority. It is obvious that none of them had a happy childhood. As mentioned earlier, Zanda and Valdis were taken away from alcoholic parents and put into special boarding schools aimed at orphans and children taken away from their parents. In these schools children grew in very poor material conditions, in most of cases mistreated by the teachers and administration as they were considered as a 'social pathology'. In fact, in the Soviet Union it was common to separate orphans and children of 'problematic' parents (mainly having dependences) from the rest of the society. After graduation from these schools the young people had to live on their own without being helped to integrate into society. So, only the strongest and those who were helped by relatives had a chance to get a college or a university and build a decent life, while the vast majority became alcoholics and multipliers of culture of poverty. For example, in the movie we see other characters, namely Andulis, Janis, Oscars, who also grew up without experiencing parental care in boarding schools, and as a result now live on the edge of absolute poverty - are unemployed, frustrated and dependent on alcohol.

In Family Instinct we see a very powerful scene in which Zanda and her mom are having a conversation about socially preconditioned misfortunes:

Zanda: Don't you feel a bit guilty about all of this, mom?

Zanda's mom: About what? That you have your brother's kids? I did the best I could for my kids.

Zanda: Would anything be different if you would brought us up yourself?

Zanda's mom: What do you mean? The others turned out normal.

Zanda: But what if would brought us up yourself?

Zanda's mom: I don't know. I'm not sure if I could have coped by myself.

Zanda: Aren't you even a bit sorry?

Zanda's mom: Yeah, I am sorry that I had so many kids. I wish, I hadn't had any of you.

Zanda: Don't you love us?

Zanda's mom: Why should I? What's there to love?

Zanda: So why keep on livi ng?

Zanda's mom: What else can we do? 
The cinematographer carefully follows this conversation between the daughter and the mother, which reveals how important for Zanda was to get a confirmation that she was/is loved by her mother. Yet, the truth was very disappointing, however predictable. Later in the movie we find out that Zanda is at risk of losing her own children because of lack of parental/social skills and discrete relationship with her brother Valdis who uses domestic violence. This shows how the poor are 'caught in a pathological cycle of ritual social crises' - as Robert C. Smith puts it - which 'have just as much to do with economics, politics, and one's larger social environment'. (Smith 2017, 1)

The misery in which Zanda and her children live is presented in an observational mode. The images of the exterior and interior of the house reveal that the living conditions are below the average of a 'decent' quality of life. The house has no bath as we find out from the scene of children bathing; the furniture and kitchen infrastructure are worn out (most probably collected from a dump). We see only few children toys - some blocks and a dirty teddy bear lying on the floor. Even the Christmas tree children decorate just with paper sheets as no decorations or presents for the kids are affordable. However, the audience gets no information about Zanda's income and can only guess that she is dependent on social assistance. The lack of relevant information makes it difficult to assess how much the wider socioeconomic conditions affect the situation of the characters.

Monetary poverty and material deprivation in this movie is shown not just as a disadvantaged and insecure economic condition but also as 'a shameful and corrosive social relation'. (Jones and Novak, 1999). Such approach highlights non-material aspects of poverty such as the lack of voice; disrespect, humiliation; shame and stigma. People living in these conditions are unlikely to improve their lives acting alone. For instance, Zanda finds herself helpless and stigmatized because of her social status, but she doesn't know how to cope with her problems, and she has no one to back her up. We observe lots of frustrations and violence in the movie, especially in drinking and partying scenes. For instance, in the episode of Zanda's birthday party there is a scene of Zanda's younger brother having an argument and later a fight with one male guest. While in other scene the camera documents the outbreak of Zanda's violent behaviour when she knocks down Andulis (who is actually the only truly peaceful character in the movie) and starts beating and kicking him while reminding his debts for electricity (in fact, the motive of un-paid bill recurs several times in the movie). In the status of not controlled anger, Zanda rolls the man towards the 
fire shouting 'I will kill you'. And finally, while calming down she desperately screams 'I am alone! I am all alone!' It is difficult to image a simpler and more poignant accusation of the society for the misery of an individual.

The return of Valdis also doesn't promise any positive changes in her life as we learn from the letters she receives from the prison and other situations. For example, in the scene of Zanda's preparations for Valdis return, she warns her brother Maris and his girlfriend Inga (who moved in after Valdis arrest) to move out of the house because 'if Valdis gets drunk he will kill you!'. Later she asks the couple: 'Aren't you afraid?' and claims 'I am. He will be really pissed!'. In the day of Valdis return, we observe the change in Zanda's behavior and mood, she became worried and stressed. The children also looked more quiet than usual. Valdis came home drank very late that day. Obvious, that he really didn't miss his family.

People who are supposed to help Zanda, namely social workers and the bureaucrats of the municipality, are not capable to do that, as they mainly care about formalities and speak a jargon people like Zanda do not understand. In the movie we follow several Zanda's meetings with social workers and bureaucrats. From them we learn that the woman is endangered to lose her children if she continues to live with Valdis in a violent environment. These scenes and an episode of Zanda's and her children's visit to their new home (a social apartment in a block e somewhere in the middle of the fields) from which they fast escape, reveal that the social workers are absolutely not capable to deal with people alike Zanda. The only solution they could find in the current complicated situation was: 'We'll put them in a flat and see what happens'.

Gauja applies a different strategy than Borzęcka for telling the story of this pathological family. He puts the bits of one year Zanda's life (documentary content) into dramatic framework (fictional form) for an exploration of socially preconditioned poverty and segregation. For Gauja documentary is a narrative form for telling a story to the audience. The story starts with a brief text on the screen informing about the venue of the movie - 'The following takes place in a village six kilometers away from a major port town in Latvia'. Later we see Zanda commenting on the subject of the movie followed by episode of Valdis's arrest. In the background we hear a conversation between Zanda and a woman (probably a neighbour) about the arrest. These scenes stimulate curiosity of the spectator and serve as a prologue introducing the protagonists and their life drama. The film ends up with an intriguing note: - 'Zanda run away from Valdis with Andulis and her 
two children five months after he returned home from prison. They moved to a secret location in another part of Latvia to try and start a new life together as a family.'

Gauja skillfully combines observational and performative modes of representation, staged scenes and raw documentary materials in cinema verité style. Being trained as a scriptwriter and a journalist he makes the type of movies which Stella Bruzzi describes as '(...) a negotiation between filmmaker and reality, and at heart, a performance' (Bruzzi 2006, 186). In an interview with Zabrizzi, Gauja claims that for him 'the story is everything, and we did everything to organize the story, to structure it, to have the focus on the main paradox, and the focus on the main protagonist; (...), and whenever we felt there was a hole in the story we tried to fill it with the necessary things, and one thing which is very important is the dialogue, because without these dialog scenes, dialog episodes, I don't think the viewer could actually read the story. So we started to construct these dialogs, and the characters actually started to feel good about it, actually they started to like to play out their lives. They became almost like actors, but anyway, everything they did was based on their experience, on their lives' (Zabrizzi 2011).

An inexperienced spectator would not even notice these film director's 'improvements' of the documentary material, because this enactment and re-enactment (in certain scenes) of own life and experiences give rise to real feelings and real meanings of predestined poverty in lives of the movie characters and many alike. This film shows that ' $(\ldots)$ performance - the enactment of the documentary specifically for the cameras - will always be the heart of the non-fiction film.' (Bruzzi 2006, 187).

In the documentary we see the life of the characters and their milieu from insider's perspective and this gives the impression of authenticity. The world observed by Grebnevs' camera is so miserable, frustrating, violent and destructive that we do not believe in the characters' abilities to get out of it without being helped by the outsiders. And this is the message which we get from the authors of the movie. However, despite its good intentions, the movie received lots of criticism at home. The drastic images of absolute poverty and social degradation in Latvian countryside raised objections against the ethics of the filmmaker. This reaction is understandable, as the movie is certainly shocking and in the scenes of violence, drinking parties and intimacies we get an impression of mistreatment of the characters due to using voyeuristic and exoticizing approach. For instance, the scene where Janis hits himself with a knife and fells down on the floor in front of Zanda, her two little children and Andulis had to be stopped being shot bearing in mind negative 
effect for the little children. We can see how they were scared. The same relates to the scene of naked Andulis and Janis dancing and afterwards hugging on the bed. In the conversation with Zabrizzi, Gauja acknowledged that these scenes were provoked by him re-enacted by the characters and he had to make ethical compromise for the sake of the story (Zabrizzi 2011). This case shows that artistic necessity not always justify drastic intervention into private lives because as Paul Ward claims 'in the documentary field, ethics commonly falls almost entirely onto the shoulders of the filmmaker' and 'the filmmaker's probability and professionalism in ensuring that they do not mislead the viewers or misrepresent their subjects'. (Ward 2008, 193). However, it is not possible to deny that Gauja succeeded in telling a very powerful story about poverty and social marginalization.

\section{Poverty and jJoy of fFatherhood in Marat Sargsyan's Father}

In contrast to Borzęska and Gauja, Sargsyan's Father portrays more glimpses of a joyful Commented [gk5]: Maybe have a title which highlights the authorial strategy of the director.

life of a poverty-stricken family than Borzecka and Gauja in their respective films. The movie protagonists Vidas Antonovas (the oldest father in Europe and a retired criminal) as well as other characters (his wife and children) are granted a bigger respect than in Thirteen and Family Instinct. as well. However, the intention to show__reveal-something exotic and bizarre is also noticeable:; most probably, (to paraphrase Elizabeth Cowie) for the pleasures of the documentary filmmaker and the audience. (Cowie 1999, 28). In Father

Wwe see the images of the poor and their milieu as if filtered through the eyes of an ethnographer, who to paraphrase Katrina Schlunke 'translates and embodies, emotional, daily complexity of bizarre ordinary life that he/she was within:' (Schlunke 2008, 222). It should be noted that before starting filmmaker's career, Sargsyan had been working at regional and commercial TV channels, therefore the search for bizarre story and an unusual character was quite acceptable for him. In interview conducted by Maldeikyte in on 26th of September 2013, he mentions that told how came to an idea to make a movie about Antonovas. Iitt was his former colleague from Šiauliai regional television- who told him about a retired criminal (known for bank and aircraft robberies), a pioneer in body-building and the oldest father in Lithuania (at a time), who might be an interesting subject for his master graduation documentary film (Maldeikyte 2013). However, from all intriguing chapters of Vidas Antonovas' life, Sargsyan chose the current 
one - of a family man, even though the portrait of Antonovas' as a criminal could be more intriguing and easy to sell to the audience.

It is worth mentioning that Lithuanian documentaries quite often depicted impoverished countryside residents as an exotic or bizarre Other. This attitude is mutual for the middle (e.g. Janina Lapinskaite, Audrius Stonys, Julija Gruodienè and Rimantas Gruodis) and young (e.g. Oksana Buraja, Linas Mikuta) generations of filmmakers. Local media also often pick misfortunate villagers for creating intriguing and engaging stories to their readers and viewers, thus Marat Sargsyan's movie is not exceptional.

It fact, it is quite easy to find a suitable character of misfortunate villager for a story, as one third $1 / 3$ of Lithuanian population live in rural areas where poverty is significantly (more than 10 percent) bigger than in the cities. According to Dovile Barčiukienè, in Lithuania this gap exists and enlarges because of lack of the programmes or actions aiming at diminishing poverty in rural areas,_especially addressing the monetary, social and cultural needs of the most vulnerable groups, such as multi-child families, children, old, handicapped and low educated citizens). She points to low employment possibilities, poor or no infrastructure for child education and leisure, humble housing conditions and big emigration of young people to the cities or abroad as the biggest maladies and disadvantages of rural areas (Barčiukienè 2007, 132). Ilona Tamulienè, also argues that the poverty remained a big problem in Lithuania after joining the EU even in the times of the economic growth, especially for the residents of rural areas and families with two and more children. Moreover, she notices the discriminatory social policy in Lithuania, which foresees smaller social assistance for the children than the adults and this enhances the risk of poverty of multi-child and single parent-families (Tamulienè 2005). Daiva Kšivickienè also indicates the same problems as her colleagues-researchers. In article "Manifestation of Poverty in Lithuanian Rural Areas" she presents shocking truth about child poverty in Lithuania - she writes that children (till 18 year-old) are deprived and live in absolute poverty much more than the adults and this creates the closed circle of miserable life. Most of children who grow up in poverty have no access to education, social and cultural development and being grownups lead the same live as their parents (Kšivickienė 2006, 85).

In Sargsyan documentary we see a provincial impoverished family raising six children and planning to have some more. The family's income is comprised of retirement pension of the father, (who at a time of shooting was 73) and social assistance money for the unemployed wife and their
Commented [gk6]: In which period?

Commented [gk7]: Maybe this can be presented in a more concise way, as thes authors make the same argument. 
children. The 'observational' camera very carefully records the signs of the extreme deprivation: broken windows and dirty unpainted walls and floor of the house, bunk like sleeping places in which there is see straw instead of mattresses and ; worn-out clothes of the kids. just to mention few. At the same time, However, in the movie (as already mentioned above) we see a picture of a happy family. Antonovas is pictured as a relaxed father enjoying his life with a much younger woman, who, as he says, 'shares a similar philosophy of life'. The partners consider kids as the joy of life and want to have as many as possible despite of health issues, old age and material deprivations. The man believes that he can prolong his life if he exercises, enjoys life and reproduces.

In the film we see Antonovas regularly sporting, playing guitar and singing, having fun with children. He looks relaxed and happy. There are many scenes of children play, singing, quarreling and laughing. We see them making fun in beds before going to sleep, running and screaming inside the house, reconstructing arrest scenes of their father and ; bathing in the lake, and etc., but in none of them we see children playing with fashionable toys or enjoying videogames, what would be common in most of families these days. We also never see children making homework, having hobbies or interacting with children from other families. It sSeems that the family is lives very isolated from the society, and in Lewis words 'immersed in the present' in own small world, what help to 'develop a capacity for spontaneity, for enjoyment of the sensual, the indulgence of impulse, which is too often blunted in our middle-class future-oriented man-' (Lewis 2006, 21). However, seeing humble diet of the children (plain rice for lunch, for snack one cookie and a cup of chocolate milk, etc.), their bold heads (most likely because of unsanitary conditions), sleeping conditions ( they don't have decent beds, matrasses and bed sheets), and tears after not receiving Christmas presents which they expected suggests, I believe that life in the culture of poverty will have destructive social and psychological consequences for these children as it had for the characters of Family Instinct and Thirteen, because deprived life in childhood 'programmes' poverty in adults life as Kšivickienè reveals in her study (Kšivickiene 2006, 85)

In the movie Sargsyan avoids clear and well build narrative for telling his character's story. The spectator has to construct the story and the portrait of the protagonist from the puzzles of his life, captured in the pictures from his personal photo album (youth and pioneering in bodybuilding in Lithuania), the video records from the prison and newspapers headlines (story of a criminal and the third marriage), Antonovas' memories and confessions addressed to the camera (memories of 
a criminal life and thoughts about his family, marriages and children) and observations/documentations of current everyday life in a family circle (happy fatherhood and relaxed retirement). Due to diverse documents presenting different chapters of Antonovas' life, spectator gets a rich picture of the character, however is not encouraged to question.- or interpret. Thant's why the film has no-streng emotional or intellectual appeal. Bruzzi claims that in documentary the fundamental issue is 'the way in which we are invited to access the "the document' or 'record' through representation or interpretation, to the extent that a piece of archive material becomes a mutable rather than a fixed point of reference.' (Bruzzi 2006: 17). In Father Sargsyan uses photos, audiovisual records and clips from newspapers rather for representational than interpretational purpose, as the movie focuses on the portrait of the Other father.

For Sargsyan and his cinematographer Linas Dabriška Father was a master graduation project, so both of them learned during filmmaking process and experimented with documentary storytelling and representational techniques. In the film uninterrupted, not staged observation is used as the main creative strategy for telling bizarre and unusual fatherhood story, however, some tactics and devises of archival puzzling and performative mode are incorporated as well. In conversation with Maldeikyte, Sargsyan revealed that he and Dabriška decided to use as little as possible interaction with their characters during shooting: not interfere in their everyday activities and not to tell them what/how they should perform in front of the camera. However, this task was not easy to fulfill as Antonovas wanted to tell his life and philosophy of living directly to the camera, but not just being observed. (Maldeikytė 2013)

The shooting took almost two years, so it was enough to build trust and friendship with Antonovas family. Father is an example of participatory filmmaking in which a role of the filmmaker, as Jerry Rothwell puts it, is 'to enable someone to articulate their experience through a filmmaking process' (Rothwell, 2008, 155). It is noticeable that the characters feel very comfortable in front of the camera and demonstrate confidence in the film director and cinematographer. We don't see drastic 'improvements' or 'exaggerations' in representations of these characters and their environment - just pure observation of daily routines and extreme poverty, which face the characters. Vidas Antonovas, his wife and children obviously enjoy being in the movie and contribute to it with performative playfulness. For instance, in one episode Vidas re-enacts one of his arrests after robbing bank. His children are instructed to play the authorities, and to repeat certain rude commands, like 'eat soil bandit' or 'show were you hide money'. Though 
the game is not very suitable for small children, it gives lots of fun and happiness. In other scenes we see the father exercising and boxing in order to keep himself fit and healthy and thus to challenge time and age. With pleasure he demonstrates his trained body and moves mussels in front of the camera. It should be noted that, certain scenes give a feeling of being staged, performed for the camera. For instance, at the beginning of the movie we observe a scene of small children sitting in beds and at full volume reading old newspaper-articles about their father's arrest, the love story of their parents and the birth of their first children.

Marat Sargsyan's Father leaves the viewer confused and raises questions about the main idea of the movie and the intension of the author. Because by presenting an idyllic and happy life of this Other family, he ignores many social and political problems which causes life in absolute poverty of families alike Antonovas. Showing a happy image of children who live in extreme deprivation the filmmaker relieves the society, politicians and public institutions aimed at assisting the poor from their responsibly in diminishing social segregation. Most probably, the approach to the poor and the problem of social exclusion, which we notice in the movie, answers why Lithuania is one of few European Union countries where the gap between the poor and the rich kept increasing despite of the economic growth and the EU aid.

\section{Conclusion}

The documentaries examined in this article, show different attempts to deal with topic of $\underline{\text { use }}$ different authorial strategies to represent poverty and social exclusion in rural areas of Poland, Latvia and Lituania. poor families. In the case of Thirteen this is a strategy of a pornographer.

While they deserve praise for broaching a topic which is barely tackled in fiction cinema, their value as social intervention is limited. This is because they focus on families which, apart from being poor, come across as very unusual, even pathological and suggest that their poverty and social exclusion has more to do with their specific circumstances, such as having many children, old age, crime, than with wider social conditions, in which they operate, most importantly neoliberalism, adopted by these three countries after the fall of the Berlin Wall. By the same token, while eliciting sympathy to their characters, they suggest that the problem of poverty is marginal rather than widespread and even absolve the state from transforming conditions under which poor people live.
Commented [gk8]: Strategy of idealization? Beautification?

Commented [gk9]: We should write here these different strategies.

Formatted: Font: Italic 
However, all of them look at this 'situation' as a social or even individual pathology. These families are represented as pathological, preconditioned by social factors, lack of education, themployment, being single parent, old age, crime, alcoholism. It can be argued that In fact, the presentation of these families as abnormal and bizarre phenomenon helped the movies to circulate within the circle of international and local film festivals, TV channels and cinema audiences. Borzęcka in Thirteen and Sargsyan in Father looks into poverty in rural areas as a personal choice and responsibility rather than a countries social problem and societal responsibility. While Gauja in Family Instinct stimulates empathy for the characters and provokes the guilt for ignoring the most vulnerable citizens. All the three films show how the poor are trapped in a pathological cycle of social problems, which are preconditioned by country's social politics and larger social environment.

\section{Bibliographical note}

Alam, Asad, Murthi Mamta, Yemtsov Ruslan, Edmundo Murrugarra, Dudwick Nora,

Hamilton Ellen, and Tiongson Erwin, 2015. Growth, Poverty and Inequality. Eastern Europe and Former Soviet Union. The International Bank for Reconstruction and Development / The World Bank.

https://openknowledge.worldbank.org/bitstream/handle/10986/7287/34043.pdf?sequence=1\&isA llowed=y

Barčiukienè, Dovilè. 2007. "Skurdas Lietuvos kaime: paplitimas, priežastys ir mažinimo būdai”, Socialine teorija, empirija, politika ir praktika, 4: 132-143.

Bruzi, Stella. 2006. New Documentary. London, New York: Routledge.

Cowie, Elizabeth. 1999. "The Spectacle of Actuality", in Collecting Visible Evidence. Visible Evidence, Gaines J.M., Renov M. Minneapolis, London: University Minnesota Press. 6: 19-45.

Cowie, Elisabeth. 2011. Recording Reality, Desiring the Real. Minneapolis, MN: University of Minnesota Press, Kindle Edition.

Jones, Chris and Novak, Tony. 1999. Poverty, Welfare and the Disciplinary State. Psychology Press.

Fromm, Erich. 2001. The Sane Society. London, NY: Routledge

Gough, Jamie, Eisenschitz, Adam and McCulloch, Andrew. 2005. Spaces of Social Exclusion. London: Routledge. 
Kšivickienė, Daiva. 2006. "Skurdo apraiškos Lietuvos kaime”, Žemès ūkio mokslai, 1: 81-91.

Lewis, Oscar. 1963. The Children of Sanchez. Autobiography of a Mexican Family. NY: Vintage Books.

Lewis, Oscar. 2006. "Culture of Poverty”. In Poor Americans (Trans-Action/Society Book Series, Pilisuk (Author), Marc Pilisuk (Editor), Phyllis Pilisuk (Editor).

Lister, Ruth. 2004. Poverty. Cambridge: Polity Press.

Maldeikytė, Živilè. Pokalbis su Maratu Sargsyanu: „Jeigu gali nedaryti, geriau nedaryti““

http://kinfo.lt/pokalbis-su-maratu-sargsyanu-jeigu-gali-nedaryti-geriau-nedaryti-2/ in http://kinfo.lt/pokalbis-su-maratu-sargsyanu-jeigu-gali-nedaryti-geriau-nedaryti-2/ 2013-09-26 (accessed on 10.27.2016)

Matthews, Mervyn. 1986. Poverty in the Soviet Union: The Life-styles of the Underprivileged in Recent Years. Cambridge University Press.

Mazierska, Ewa. 2007. Polish Postcommunist Cinema. From Pavement Level. Peter Lang Peter Lang International Academic Publishers.

Renov, Michael, Introduction: The Truth about Non-Fiction, In: Theorizing Documentary. New York \& London: Routledge. 1993, 1-11.

Rothwell, Jerry. 2008. Filmmakers and Their Subjects, in Austin, Thomas; de Jong, Wilma (eds.) Rethinking Documentary. New Perspectives, New Practices. 152-156.

Scott MacNeil, Lela. 2011. Meet the Filmmaker: Andris Gauja ("Family Instinct"), http://rooftopfilms.com/blog/2011/06/meet-the-filmmaker-andris-gauja-family-instinct.html , June 25, 2011

Smith, C. Robert. 2017. Society and Social Pathology: A Framework for Progress. Cham, Switzerland, Palgrave Macmillan.

Zabrizzi, Paul. A Conversation With Andris Gauja (FAMILY INSTINCT), In: http://www.hammertonail.com/interviews/a-conversation-with-andris-gauja-family-instinct/),

June 26, 2011

Tamulienė, Ilona. 2005. "Skurdo problemos ekonominio augimo sąlygomis Lietuvoje”, $L \check{Z} \bar{U} U$ Mokslo darbai, 68 (21): 87-94.

Townsend, Peter. 1979. Poverty in the United Kingdom, London, Allen Lane and Penguin Books. 
Ward, Paul. 2008. Drama-Documentary, Ethics and Notions of Performance: The 'Flight 93'

Films, in Austin, Thomas; de Jong, Wilma (eds.) Rethinking Documentary. New Perspectives, New Practices. New York: McGraw-Hill/ Open University Press. 191-203. 